\title{
A ORganicidade MUSiCAl De DiVina QUIMERA (1916), DE EDUARDO GUIMARAENS
}

\author{
Ellen Guilhen \\ Andréia Anhezini
}

\section{INTRODUÇÃO}

Lucrécio, em De rerum natura [Sobre a natureza das coisas], emprega o substantivo orgănĭcus para designar músico, instrumentista. O adjetivo latino homônimo indica algo relativo a instrumento musical ou mecânico. Em português, orgânico pode tanto substituir fundamental, essencial, inato quanto remeter a organismo, constituição, compleição, ordem, combinação, temperamento, conjunto, disposição (no sentido de arranjo, colocação). Investigar a organicidade de Divina quimera - livro de poemas do gaúcho Eduardo Guimaraens (1870-1921) publicado há exato um século - significa, portanto, indagar acerca dos mecanismos que fazem desses poemas um conjunto, seres pertencentes ao mesmo corpo. Ao priorizar a acepção original latina, ligada à música, indicamos que o título deste artigo poderá ser lido como uma tautologia.

Para entendermos a configuração do livro, começaremos pelo índice da primeira edição:

Prelúdio

Parte I - 1 a 17

Parte II 
1 Dante

2 Chopin: prelúdio n. 4

3 Túmulo de Baudelaire

4 A Stéphane Mallarmé

5 De profundis clamavi

6 Sobre o "Cantico delle creature"

7 Nox

8 [Tudo que faz da carne um mistério inquietante]

9 Misterium

Parte III - 1 a 7

Parte IV - Sonata sentimental

Parte V - 1 a 13

Final

Poemas numerados, partes claramente divididas, um "Prelúdio" que abre, um "Final" que encerra, a presença dos mestres Dante, Baudelaire, Mallarmé, Poe - autores de obras de estrutura definida ou de textos críticos que as propõem: há claros sinais de que Divina quimera não se define como uma simples recolha de poemas, mas como obra cuidadosamente arquitetada. Procuramos na viagem ascensional da Divina comédia e na parábola de As flores do mal semelhanças quanto ao traçado mas, embora essas obras estejam presentes de modo inequívoco no livro, da epígrafe ao verso final, não são elas que ditam o esqueleto organizador. Mallarmé, Poe, quem entregará a chave (clave) de leitura?

\section{PRELÚDIO: IMPROVISO MUSICAL OU TESE LITERÁRIA?}

O título do primeiro poema indica proximidade com a música e pode nos oferecer pistas. Vamos a ele:

\section{Prelúdio}

Das rosas do jardim, a virginal tristeza por que, por esta noite azul de outono frio, vem embalar-te a doce e mística pureza que reflete, a um fulgor de estrelas erradio, das rosas do jardim a virginal tristeza? 
Um desejo augural, sob o candor de linho que do teu corpo aviva a palidez, palpita. Perfumaram-te a carne os lírios do caminho... Vela-a, agora, através do meu amor, Perdita, Um desejo augural, sob o candor do linho.

Tal num sonho de amor que se dilui sereno, Esqueceste a carícia rósea do sorriso; $\mathrm{E}$ a tua boca sente o acre sabor terreno De uma desilusão no destino indeciso, Tal num sonho de amor que se dilui sereno.

Vista-te o sono de dolência o odor das rosas que espreitam do jardim, maravilhadamente, do teu secreto sonho as horas misteriosas! Olvidaste, afinal, o teu delírio ardente? Vista-te o sono de dolência o odor das rosas!

Dize-me se a tua alma adormeceu sorrindo ou se, cheia de amor, insone, se recorda das rosas por abrir de um sonho antigo e lindo, destas rosas febris, da sombra eterna à borda? Dize-me se a tua alma adormeceu sorrindo!

Serás como uma vaga aparição de outrora, como a madona singular de um Primitivo. (Possa o teu sono ser a noite sem aurora!) Por um mês de Maria, ao meu desejo esquivo, serás como uma vaga aparição de outrora.

Que doce o teu palor! Que estranha a tua face! Nimba-te a fronte um halo, um resplendor, brilhando, Por que entreabres o olhar à alva do sol que nasce? Vais unir, sob a luz, as tuas mãos, orando? Que doce o teu palor! Que estranha a tua face!

Não despertes, porém, ainda que surja o dia! Dorme perpetuamente o sono teu sem termo, ó forma de vitral, Musa e Melancolia, que és a quimera de um espírito enfermo! 
Não despertes, porém, ainda que surja o dia!

- Das rosas deste amor a musical tristeza por que, por esta noite azul de outono frio, vem embalar, da sombra, a tua morbideza que ouve e sofre, a um clarão de estrelas erradio, das vozes deste amor a musical tristeza?

(GUIMARAENS, 1944, pp. 135-136)

Derivado do termo latino praeludium - preparo, ensaio -, convencionou-se atribuir o título "prelúdio" a peças musicais breves que antecedem a execução de uma obra de maior fôlego. Devido à posição introdutória que ocupa, é o momento do teste de uma ideia, do exercício dos músicos em torno de um motivo ou frase melódica, tempo de aquecimento e improvisação. Caso considere a sequência melódica inacabada, imatura ou desagradável, o compositor pode, nessa forma de composição, retomar o ponto de partida (motivo inicial) para redesenhar o trecho subsequente ou mesmo reiniciar a execução a partir de outro ponto, até que o resultado esteja a contento.

Por outro lado, na tradição literária, o primeiro poema se apresenta, inúmeras vezes, como uma profissão de fé, um indicativo dos rumos e valores daquela poética, espaço explicativo das escolhas éticas e/ou estéticas do escritor, à guisa de prefácio. O "Prelúdio" de Divina quimera de Eduardo Guimaraens se encaixaria, afinal, em qual categoria: improviso ou prefácio? Teste de sequências melódicas ou tese poeticamente apresentada?

Observemos um de seus traços mais evidentes:

"Prelúdio" abre com uma pergunta e fecha com uma pergunta, levantando outras no percurso. As perguntas, dirigidas a um tu que não responde, suspendem o poema no ar. Toda pergunta abre sendas ao lugar em que há suspeita de resposta. Mas o que esperar de perguntas que caem no vazio? Que sentido tem falar a ouvidos que não ouvem? As perguntas, desamparadas de resposta, por explorarem o insondável, cultivam a dúvida (SCHÜLER, 1986, p. 21).

Além das perguntas sem respostas, as certezas provisórias também colocam o poema em permanente indefinição: um desejo palpita sob a palidez, na segunda estrofe. Na seguinte um sonho de amor se dilui, sereno. Na quarta o sonho volta e o eu lírico não sabe mais se a amada esqueceu o delírio ardente (v. 19). O desejo que lateja e renasce na 
segunda estrofe torna-se esquivo na sexta. Como interpretar um poema com destino tão indeciso (v. 14)? Há um desejo? Houve? Ele continua vibrando? Há memória? O que vale, por fim: a afirmação de que a amada esqueceu a carícia (v. 12) ou a dúvida do verso 19 - "Olvidaste, afinal, o teu delírio ardente?"?

Podemos dizer quea obsessão de "Prelúdio" (e da Divina quimera como um todo) por algumas tópicas - sonho, sono, esquecimento, fulgor, rosas, jardim, sombra - (aparente bloqueio criativo) e a oscilação dos sentidos a elas atribuídos (desejo augural que palpita e que vela [encobre] a carne; rosas que causam dor ao sono e se deleitam com o sonho da interlocutora; a musical tristeza que embala a morbidez a partir da sombra, mas que é ouvida [apenas?] no clarão erradio de estrelas, entre tantos outros) aproximam o poema do sentido usual de prelúdio em música, ligado ao improviso e ao teste de uma ideia.

Cabe lembrar, entretanto, o objetivo desse teste: construir uma sequência melódica que agrade, dar nome e forma (mesmo que aberta) a estados de alma erradios, encontrar o tom que guiará a extensa obra seguinte (seria o prelúdio um pré jogo? Pré lúdico?). É válida, portanto, a pergunta: qual temática se firmará?

"Não despertes" - o imperativo negativo que abre a penúltima estrofe parece atrair, inclusive ritmicamente, a atenção. A estrofe dá outro nome à interlocutora (na estrofe 2 denominada Perdita) - "Musa e Melancolia" - e a define como "a quimera de um espírito enfermo!", trazendo à cena a palavra-chave do título do livro. Para entendermos essa Musa (contração de música) que é melancolia, Perdita e quimera, recorremos às reflexões de Giorgio Agamben (2006, p. 61) em torno da melancolia - "processo erótico impregnado de um ambíguo comércio com os fantasmas”, de acordo com certa tradição medieval:

Recubriendo su objeto con los ornamentos fúnebres del luto, la melancolía les
confiere la fantasmagórica realidad de lo perdido; pero en cuanto que ella es el
luto por un objeto inapropiable, su estrategia abre un espacio a la existencia de
lo irreal y delimita una escena en la que el yo puede entrar en relación con ello
e intentar una apropriación con la que ninguna posesión podría parangonarse
y a la que ninguna pérdida podría poner trampas (AGAMBEN, 20o6, pp. 53-54).

Recuperando o ensaio "Luto e melancolia" de Freud (1917), Agamben entende o delírio melancólico não tanto como uma reação regressiva ante a perda do objeto de amor, o fim de um passado feliz ou de um mundo subjetivo, mas a capacidade fantasmática de fazer aparecer como perdido 
um objeto inapropriável, a apropriação do objeto justamente na medida em queafirma sua perda (2006, pp. 53-54). É apenas na existência do irreal, da quimera, que o eu lírico interage com o objeto de sua afeição. Devidoà sua ambivalência - o possuir (apenas) na perda -, a intenção melancólica só se manifestaria sob as leis do inconsciente. Ora, nada melhor do que o entorpecimento musical para aflorar esse mecanismo, processo que discutiremos na próxima seção. Em suma, o pedido/conselho/ordem por um embalo sem termo, por uma ilusão que não abra os olhos "à alva do sol que nasce" (v. 33) - tema que se define em "Prelúdio" - lembra que o fim do delírio é o fim do amor, o fim da posse (impossível) e da poesia.

Mas como seria possível dormir sobre uma dor? Ter paz sobre a imprecisão? Esta é a pergunta da primeira versão da estrofe 3, apresentada na edição de 1916 da Divina quimera, e transcrita na segunda nota desta análise. "C'est un des privilèges prodigieux de l'Art que l'horrible, artistement exprimé, devienne beauté, et que la douleur rythmée et cadencée remplisse l'esprit d'une joie calme" (BAUDELAIRE, 1975-1976, II, p. 123, grifos do autor), propõe o grande poeta francês. Crendo nesse poder tranquilizador da arte, o eu lírico celebra, na última estrofe, a musical tristeza das vozes de seu amor que vêm embalar a morbidez da amada. Do mesmo modo, dentro do raciocínio circular que caracteriza o poema, interroga qual motivo/ explicação para que, a partir da sombra e graças a um clarão erradio de estrelas, essa morbideza ouça e sofra tal tristeza musical.

Manter no poema a suspensão, a dupla direção, não é só uma escolha temática, mas uma aposta ética e estética de Guimaraens. Isso significa que podemos ler "Prelúdio" tanto como teste quanto como tese ou, ainda, como uma tese que se apresenta como e a partir de um teste (também musical). Recordemos, a seguir, alguns pressupostos e valores da tradição literária, à qual o poeta se filia, para que nos ajudem a dimensionar a extensão de sua proposta formal.

\section{ÊXTASE MUSICAL, CONTEÚDOS INQUIETOS E FORMA TRANQUILIZADORA}

A primeira missão do poeta, sobretudo numa época materialista, é recapturar o sentido misterioso da existência, advoga Mallarmé. Por meio da sofisticação da linguagem e da lógica musical, ele encontraria uma alternativa à racionalidade, embora isso representasse apenas "névoas" que disfarçariam temporariamente sua impotência diante do Azul. 
A música, com sua capacidade de sugerir mais de um nível de imagens, lança a essa poesia o desafio de provocar no leitor uma liberação onírica semelhante ao êxtase de Baudelaire diante de Tannhäuser, de Wagner. Os múltiplos significados contidos nas palavras e em suas combinações seriam os ingredientes dessa aposta. E, com tal profusão de sentidos, o poema se tornaria um enigma (BALAKIAN, 2000, pp. 40 e 42).

Dito de outra forma, o estilo críptico de comunicação levaria à perda da referencialidade e, assim, prepararia terreno para exploração do ininteligível por outras faculdades que não o juízo lógico. "Recusando-se à enunciação clara, o poema se oferta como uma espécie de celebração sensorial, da qual o poeta aparece como sacerdote oficiante", Ricieri (2007, p. 25) completa, a respeito de "Antífona", de Cruz e Sousa. Em "Prelúdio", para celebrar o culto dos sentidos, o poeta se apresenta como um intermediário específico: o áugure (v. 6 e 10), sacerdote romano que tirava presságios do voo e canto das aves, ouvinte atento capaz de, por meio dos sons, entrever o Mistério.

Nesse poema, parte do embaralhamento do racional se dá pela recombinação sintática: como vimos, o primeiro verso de cada estrofe repete-se ao final da mesma, estabelecendo uma outra e nova relação com os versos que o antecedem e fechando/formando um círculo. Nove círculos. Como as progressões de Dante no Paraíso e como as stanzas de "L’Azur" de Mallarmé, tal quantidade de estrofes remete ao nove sacral, os nove degraus e/ou esferas acima das quais a alma deve elevar-se para penetrar o véu que encobre o que é terreno e, enfim, reconhecer sua essência verdadeira, como prescreve mística cristã conhecida por ascensio ou elevatio (FRIEDRICH, 1991, p. 48).

Como, porém, admitir, sem desconforto, a restrição e o retorno representados pelo círculo numa poética e num poema que se pretendem à expansão, à elevatio espiritual, à multiplicação das experiências e das revelações do Mistério? Peter Broome procura resolver esse impasse ao discorrer a respeito de "Le balcon" [A varanda], poema de Baudelaire que emprega a mesma estratégia formal de "Prelúdio":

Each stanza is indeed a universe, unus versus, a oneness turning, a circle of unity. It is remarkable how frequently euphoric moments in Baudelaire "qui chantent les transports de l'esprit et des sens" (OC I, p. 11) conjure up images of circularity (BROOME, 1999, p. 133).

Ele não é o único crítico que destaca, na obra de Baudelaire, o descompasso entre os conteúdos insolúveis, permanentemente abertos, 
e a salvação proposta em formas organizadas, “repousantes", fechadas em si mesmas; Hugo Friedrich também o faz, incluindo, entre os conteúdos inquietos, os desassossegos de uma dualidade atormentada, que não se deixa definir.

Se refletir a ordem do cosmo criado nas formas de composição era uma pretensão simbólica da Alta Idade Média - como podemos conferir na rigorosa estruturação numérica da Divina comédia, de Dante -, Friedrich (1991, p. 40) lembra que para Baudelaire as formas não reproduziriam a ordem espiritual que organiza o mundo, antes seriam o meio de organizar o mundo, "meios da salvação, buscados ao máximo num estado espiritual extremamente inquieto".

Mas conteúdos inquietos não deixam degritar sob formas organizadas. Em Baudelaire "não há nunca uma sensação triunfal de compreensão; a mensagem permanece tão ambígua quanto sucinta, como as visões que surgem no estado de sonho", observa Anna Balakian (2000, p. 42), que acrescenta: "No estado poético a ambiguidade é alcançada como parte do processo de construção do poema-enigma”. Isto é, a ambiguidade marca a agitação de um estado de espírito, mas também é o objetivo dessa poética que ousa recapturar o sentido misterioso da existência ao buscar o inapreensível, o indefinível.

Essa tensão/indefinição aparecerá no poema inicial e no livro de Guimaraens de diversas formas. Uma delas será por meio das ambivalências, dos oxímoros. Friedrich (1991, p. 46) lembra que essa é uma figura de linguagem "apropriada para exprimir estados complexos da alma" e que o próprio título da obra magna de Baudelaire guarda/revela essa dissonância fundamental: As flores do mal - a delicada beleza e a força destrutiva.

O título Divina quimera partilha da mesma força dissonante, embora o embate não seja mais entre satanismo/mal-estar e delicadeza. $\mathrm{O}$ adjetivo "divina" estabelece o sobrenatural, o sagrado, sinaliza um passo em direção à crença de que a perfeição (o feito por inteiro) e o sublime são, de algum modo, possíveis. O substantivo "quimera" derruba essa positividade e lembra que a experiência mística de completude é ilusória e/ou provisória. Em movimentos de subida e descida simultâneos, o eu lírico é alçado às mais altas imensidades ("mística pureza”, "delírio ardente”, "um halo, um resplendor") para, no mesmo instante, ver instituídas a dúvida e a perda ("sombras", "esquivo", "ameaça de sol”). Tal hesitação não indica, porém, a prevalência da morte sobre o voo, porque o oxímoro impede a anulação de 
um ou de outro termo da equação: a quimera continua divina, e o divino, quimérico. São indissociáveis.

A descrição dessa contradição essencial aproxima-se da que caracteriza a poética de Alphonsus de Guimaraens:

Decaído e condenado à imanência, o homem define-se por sua dupla condição de sonhador encarcerado. Também o poeta decadente experimentará esse martírio. Oprimido entre o desejo de fusão mística e os limites da própria linguagem, ao poeta restará lamentar a queda, a perda, a ausência eterna de um objeto amado (VERAS, 2016, p. 82).

O resultado dessa dicotomia fundante não é, entretanto, o mesmo para os dois poetas. Se Alphonsus estaciona sua angústia na incapacidade de cantar o Absoluto que vislumbra, no desconforto da sua condição de prisioneiro (sobretudo dos limites da linguagem), Eduardo frui na música - capaz de vivificar e produzir memória - a beleza do sonho: ele não se sente preso em sua expressão. Se a palavra não barra seu voo, a poética de Eduardo chega a ser uma orquestração de encontros divinos? Divina quimera se configura, de fato, como uma sinfonia à bem amada (JAHN, 2012, p. 32)?

\section{DIVINA SINFONIA?}

Composição musical escrita para orquestra, geralmente dividida em quatro movimentos: (1) alegro, (2) andante ou adágio, (3) minuete ou scherzo e (4) rondó ou alegro vivo, a sinfonia pode ser entendida como um gênero textual, uma forma de discurso. No período clássico, era estruturada da mesma maneira que a sonata: um primeiro movimento rápido, com a exposição, desenvolvimento e recapitulação dos temas principais, podendo algumas vezes ter uma introdução lenta; o segundo movimento sempre lento ou moderado, sem uma orientação determinada quanto à forma, e o terceiro movimento mais rápido que o primeiro, geralmente estruturado como um rondó.

Para afirmarmos que Divina quimera está ordenada como uma sinfonia seria preciso encontrar paralelos entre a forma musical e a sequência de poemas. De início já encontraríamos dificuldade em fazer equivalerem as sete partes do livro à estrutura que acabamos de descrever. 
O título da Parte IV - a única nomeada - este sim indica, com alguma segurança, a proximidade entre a forma-sonata e a sequência de poemas. Comparemos:

IV

\section{SONATA SENTIMENTAL}

Deux spectres ont évoqué le passé.

(Verlaine)

1

Ora, pelos salões, calaram-se os violinos.

Sob a dolência em que se afastam os violinos,

fecham-se os lábios que se abriam para o sonho.

Vaga por tudo um fluido etéreo, um tom tristonho

de lua morta. Ei-los sem luzes, finalmente, os grandes lustres de cristal resplandecente.

E sós, pelos salões onde os sons recordaram, Schumann e o teu Silêncio, extáticos, ficaram;

os espelhos, ladeando a sala escura e enorme, refletem a tristeza esparsa que não dorme e, ao fundo dos salões, a alma das cousas mortas, insone e fantasmal, anda cerrando portas.

2

Como se fosse ainda viva em mim a melodia do teu nome, deixei que a secreta agonia da sombra amortalhasse o meu desejo mudo. E abri certa cortina imensa de veludo vermelho, que velava um salão olvidado, onde dançavam ainda as sombras do passado, cingidas de ouro, sob um halo que se fana, ao ritmo langue de uma lânguida pavana. 
3

Dentre os pares que então dançavam, lentamente procurei (não em vão!) a tua sombra ardente,

de alvas mãos de rainha e olhos iluminados, largos, profundos, infantis, martirizados

pelo lilás cilício estranho e doce e brando das grandes, místicas olheiras, cintilando.

4

ADAGIO APASSIONATO

E quis falar-te. E do teu vulto, passo a passo, como febril, aproximei-me, passo a passo

- "Quero saber da tua boca, Peregrina, se ainda o meu nome te perturba e te fascina.

Se ainda, através de todo o mal, de todo o encanto, fui a saudade que consola e seca o pranto.

Se ainda, afinal, a vida (o horto fechado!), a vida pode ser para nós como um jardim de Armida, como um desejo de Belkis que o tédio invade ou como o sonho de uma insone Scheerazade!

Fala: e o passado, grave e mudo, triste e lindo, entrega as minhas mãos às tuas mãos, sorrindo.

Porque ainda te amo agora e, ao fim de tudo, embora! quero-te mais, talvez, do que te quis outrora!

Quero-te, pelo mal do teu fugaz delírio, pela tua amargura e pelo teu martírio!

Pelo primeiro engano em que a ilusão perdeste, por tudo que sofri, por tudo que sofreste! 
Pela esperança de uma inútil elegia, de uma recordação dolente e fugidia!

E foi o meu amor o grande lírio triste que embalsamou, da sombra, a mão com que o feriste!

E amo-te ainda! E, ao fervor que a ambos nos prostra agora, quero-te mais, talvez, do que te quis outrora!

\section{5}

E, calado, esperei. Olhei-te. Um gesto lento moveu as tuas mãos: mas, como um pensamento

recíproco, inclinei a fronte. Humildemente, sorri. Beijei-as longamente, docemente...

(E esquecemos, sem nada ver, os outros pares que nos olhavam, mas com olhos singulares

que são os olhos dos espectros do passado, das sombras pálidas que voltam do passado

e erram, sob o fulgor do meu olhar tristonho, pelos grandes salões fantásticos do sonho).

\section{(GUIMARAENS, 1916, pp. 72-76)}

Em busca de um tempo impossível, esse narrador lírico compõe sua sonata sentimental, fruindo em sonho triste o dançar da pavana (2), o contato visual com a amada rainha (3), o cortejo verbal (4), o beijar das mãos (5), até que se vê, novamente, diante dos salões fantásticos da memória e do sonho. É pela contemplação do espaço vazio - os salões em que calaram os violinos (v. 1, 1) - que a vivência do encontro (e não apenas a reminiscência) se torna possível. Somente pela quimera (ilusão) ele toca o divino, o que remete à escolha do título do livro, oxímoro indissolúvel.

Essa sequência narrativa encaixa-se com justeza nos três "espaços de ação" que caracterizam a estrutura básica da forma-sonata, a "forma musical por excelência" (GRIPP, 2010, [s.p.]): 


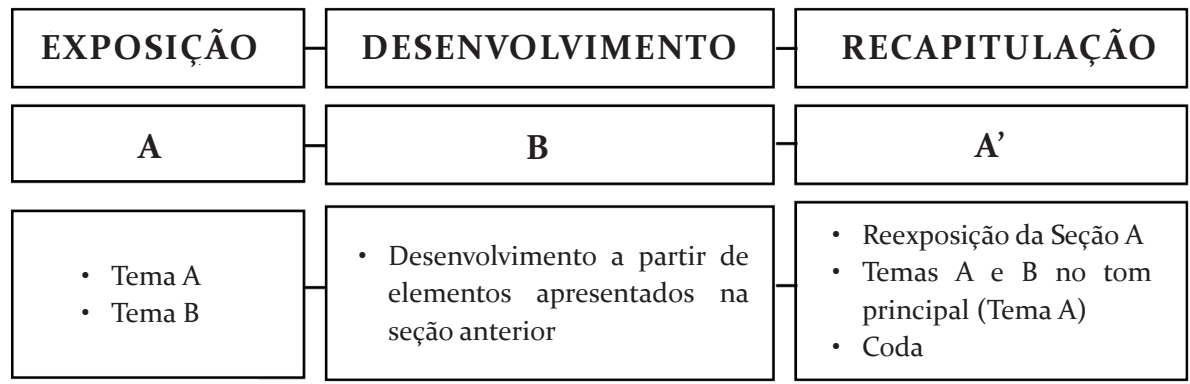

Quadro 1: Estrutura da forma-sonata (GRIPP, 2010, [s.p.]).

Descreveremos, a partir dos trabalhos de Gripp (2010) e de Machado e Monteiro (1994), o modo como se organiza cada uma das partes na música para, na sequência, estabelecermos um paralelo com as subseções do poema. ${ }^{1}$

Em música, grosso modo, tem-se:

- Exposição: “[a] peça começa com o estabelecimento de uma tonalidade, que é a tonalidade original e a tonalidade objetivo de todo o movimento. A introdução da segunda tonalidade insere na obra um elemento de dissonância que exige uma conclusão, uma volta”, explica Gripp (2010, [s.p.]);

- Desenvolvimento: acentua-se a dissonância. Os dois temas se opõem, entram em conflito, levando ao clímax. A fluência nessa seção é mais rápida, normalmente traduzindo-se em passagens mais agitadas. E o ritmo harmônico também é mais intenso, várias tonalidades são aludidas, sem que nenhuma cadência se fixe até o final da seção. Gripp (2010, [s.p.]) destaca que "todas essas características fazem do desenvolvimento o momento central: é nele que o drama todo se localiza e a tensão da separação da tonalidade principal se torna máxima”;

- Recapitulação/Reexposição: essa tensão será liberada de alguma forma. "Além da repetição dos temas já tocados na Exposição, o segundo tema passa a ser apresentado na tonalidade principal da peça, ou seja, ele perde sua "cor" própria, concluindo assim o longo movimento iniciado pela primeira modulação", completa Gripp (2010, [s.p.]). Os dois temas

1 O Índice da $1^{a}$ edição não lista os poemas da Parte IV, apresentando-a apenas pelo subtítulo Sonata sentimental". Como o subtítulo só se concretiza na soma das cinco subseções e como essa é a única das Partes cujos poemas não são numerados no Índice, entendemos que a Parte IV se organiza como um único poema.

Remate de Males, Campinas-SP, v. 37 n. 1, pp. 37-57, jan./jun. 2017 
(ainda que com suas individualidades opostas) são reconciliados, pois passam agora a se localizar em uma mesma tonalidade.

Por fim, a $\operatorname{coda}^{2}$ (cauda) dilui e/ou reafirma a tonalidade inicial, encerrando a obra.

Ao aplicarmos essa divisão ao poema "Sonata sentimental", temos a seguinte configuração:

- Exposição: a apresentação do tema A, que caracteriza o início da Exposição, corresponde ao tema do silêncio e do salão vazio. Toda a seção 1 se desenrola nessa cena, nesse matiz diluído e pouco iluminado que definiria a tonalidade central da peça. A seção 2 inaugura um movimento, ainda envolvendo sombra, mas com algum calor. A memória do baile e das sombras representaria, portanto, o tema $\mathrm{B}$, a dissonância/discordância, inaugurando a tensão: afinal, o tema dessa sonata é o silêncio (tema A) ou a dança (tema $B$ )? O fim da festa (tema $A$ ) ou a vivência desta (tema $B$ )? Solidão (tema $\mathrm{A}$ ) ou encontro (tema $\mathrm{B}$ )? A análise do poema demonstra que tema A e B se alternam e se combinam de tal modo imbricado que nenhuma tonalidade se afirma sem que a outra esteja intrinsicamente presente ou apareça na sequência: a descrição da dança carrega elementos sonoros de fim, e o salão vazio é ocupado por sombras. A seção 3 leva adiante o recorte proposto pela 2, particularizando uma figura - a da amada - dentro do rol de dançantes. Ele parece indicar que o "conflito" principal se dará entre eu lírico e essa sombra específica. A Exposição engloba, portanto, cenário, cena e amada, e o decréscimo no tamanho das seções (de seis dísticos para quatro e depois para três) destaca esse enfoque progressivo;

- Desenvolvimento: o “Adagio apassionato", a seção 4, é o desenvolvimento: o ritmo é mais rápido em relação à Exposição, a tonalidade é um pouco mais colorida, mas não chega a ser impulsiva e vibrante. Dor e prazer se chocam e se combinam com maior intensidade. O exotismo, o desejo, a interpelação marcam grande distância em relação à seção 1 , isto é, ao tema inicial (A);

- Recapitulação/Reexposição: a segunda palavra da seção 5 já anuncia que a recapitulação do poema inicial está em curso: "calado". Os olhos que se multiplicam aqui não estão presentes na seção 1; no entanto, o tema A é justamente caracterizado pelo aspecto visual, pela observação

2 Coda é o floreio final de um trecho musical; o pequeno trecho - em geral uma repetição de motivos iniciais e/ou principais da obra - que indica que a música está acabando. 
do espaço vazio e silencioso. O segundo tema (B) - a vivência do encontro - reaparece aqui modulado por advérbios e adjetivos de prolongamento e lentidão: "lento", "humildemente", "longamente", "docemente", o que poderia ser lido como uma aproximação da tonalidade inicial de abandono e silenciamento (tema A). Por fim, as rimas finais dos dois últimos versos repetem, de modo invertido, as dos versos 3 e 4 da subseção 1.

A coda confirma qual é a tonalidade central do poema, o tema principal para o qual a sonata converge: os "grandes salões fantásticos do sonho", o verso final.

Percebemos que a forma-sonata é, antes de tudo, uma forma simétrica, "porque cada um de seus elementos nessa comparação é respondido com um outro a ele relacionado" (GRIPP, 2010, [s.p.]) na busca por equilíbrio. É uma forma narrativa também, na medida em que apresenta um estado inicial desestabilizado pela chegada de outro, explora o aumento do conflito entre essas duas proposições e encerra num desfecho minimamente apaziguador. É o que nos dizem Machado e Monteiro (1994, [s.p.]):

Retirando elementos principalmente da ação dramática, a forma-sonata dava à música não só expressão e sentimento, mas um efeito narrativo, de intriga e resolução. [...] Sua dramática estrutura era que dava significado aos temas, e não suas modificações, como na fuga.

Diante de uma estrutura tão demarcada, com movimentos claramente concatenados, concluímos que propor a leitura de toda a Divina quimera como uma sinfonia - forma derivada da sonata - é temerário e improdutivo. Mas isso não significa desistir de procurar na forma da música, como preconiza Mallarmé, e não nos sons dela, como praticou Verlaine, os mecanismos que fazem desses poemas um conjunto, a meta deste artigo.

Sigamos o Mestre Stéphane. Para ele, "não eram as imitações dos sons musicais que seriam frutíferas, mas a anatomia, a estrutura do tema e variações, que substituíam a progressão lógica" (BALAKIAN, 2000, p. $70)$.

\section{TEMA E VARIAÇÕES?}

Ora, tema e variações é uma forma de composição em música na qual o tema é apresentado em geral em duas frases (entre oito e dezesseis compassos, em média) e sucedido por diversas transformações delas, 
revelando a capacidade do compositor de criar e de se exercitar em torno de um material, a princípio, restrito. As mudanças podem se dar no plano da harmonia, da melodia, do ritmo, do contraponto, do timbre, da orquestração, ou de qualquer combinação deles. Para isso, o autor pode optar por:

- Modular o tema (mudando de tom ou tonalidade);

- Transpor (mudar a altura);

- Espelhar o tema (imitar a melodia noutra voz, a partir de outra nota inicial);

- Inverter (inversão da direção melódica na pauta);

- Executar retrogradamente (inverter a melodia, tocando da última à primeira nota da frase temática);

- Imitar (imitação do contorno melódico da música com diferenças nos intervalos ou duração das notas musicais);

- Variar o ritmo (diminuindo a duração de cada nota do motivo inicial);

- Mudar o tempo da dinâmica etc.

A liberdade formal de tema e variações em relação ao prelúdio é menor: se naquela forma o compositor não precisaria se prender à ideia musical primeira, podendo alterar seu ponto de partida até alcançar a sequência de seu agrado, aqui a proximidade com o tema inicial é constitutiva, inescapável. A essência, o traço primário, se mantém, não importa quantas modificações sejam propostas.

No entanto, é necessário dizer, há um dado que destrói essa hipótese de leitura: uma obra construída nos moldes de tema e variações não poderia conter em seu interior uma forma-sonata, como a evidenciada na Parte IV. Além disso, o tema inicial deveria ser reconhecido como fundante de/em cada um dos poemas, aposta que exigiria certa violência interpretativa.

Antes, porém, de desistirmos de ler o livro sob a lógica de uma única forma musical, voltemo-nos ao arranjo das Partes no livro.

\section{FANTASIA}

Na configuração da Divina quimera, observamos uma clara alternância de caráter: as Partes I, III e V possuem estruturas mais livres, e se assemelham muito entre si quanto à tonalidade e atmosfera que 
carregam. As Partes II e IV, de formato mais rígido, parecem não dialogar formalmente com as demais, mas não deixam de apresentar motivos comuns ao restante da obra.

Comparemos essa disposição ondulatória com os princípios da forma musical fantasia, que Julio Bas (1986, p. 326) elege como basilares: 1) existência de temas, principais e secundários; 2) retorno eventual deles, no transcurso da peça; 3) delimitação de períodos distintos; 4) contraste de carácter entre eles; 5) eventual separação das várias partes ou tempos.

Ao fazer uso de notável liberdade de alternância, a fantasia destaca a força dos contrastes, não sendo rara certa brusquidão, como observamos entre as Partes I e II da Divina quimera: à fluidez da primeira, sucedem-se sonetos mais atormentados, de febril embate espiritual. Com frequência a fantasia emprega o estilo da improvisação, a quem é tributária, sendo comum que partes ou períodos com temas concretos e forma mais fechada sobrevenham a frases, períodos e amplas figurações com caráter indeciso, de transição ou passagem. O movimento inverso (partes indefinidas e mais livres executadas após formas de estrutura mais fixa) também é possível:

[...] a Fantasía debe contener una afirmación tal, que permita satisfacer plenamente el sentido musical; sea que el todo converja hacia el final como una ola que emerge o como una sucesión de aspiraciones siempre ascendentes; sea que, después de alcanzada su máxima tension en la parte central del trozo, se retorne suavemente a lo incierto, a lo indefinido, como acontece en la curiosa y vigorosa Fantasía para órgano en Sol Mayor del vol. IV (Ed. Peters) de Bach (BAS, 1986, p. 327). ${ }^{3}$

O segundo movimento descrito por Bas ajusta-se de modo bastante peculiar à última alternância do livro: à rígida e delimitada forma-sonata da Parte IV, que narra o beijo (de mão!) das sombras-amantes, segue-se a Parte V, que contém os poemas mais longos e descritivos, representando um retorno a estruturas e temáticas mais diluídas e indefinidas.

Quanto à existência de temas principais e secundários, para cada imagem, palavra ou motivo do "Prelúdio", há um ou mais poemas que o desenvolve(m). Seriam eles os temas secundários. Listamos alguns exemplos, com a menção aos poemas nos quais se destacam: solidão

3 “[...] a Fantasia deve conter uma afirmação tal que permita satisfazer plenamente o sentido musical; seja convergindo o todo para o final como uma onda que emerge ou como uma sucessão de aspirações sempre ascendentes; seja, depois de atingir sua tensão máxima na parte central da peça, voltando suavemente para o incerto, para o indefinido, como acontece na curiosa e vigorosa Fantasia para Órgão em Sol Maior de Bach.”

Remate de Males, Campinas-SP, v. 37 n. 1, pp. 37-57, jan./jun. 2017 
(Parte I, poema 2), aparição (Parte II, “Misterium”; Parte III, 7), sombra (Parte III, 1), vozes (Parte I, 11; Parte III, 1), musical tristeza (Parte II, "Chopin"; Parte III, 2; Parte III, 5), rosas (Parte V, 7), outono (Parte I, 9; Parte III, 3), insônia (Parte I, 7), jardim (Parte I, 3; Parte III, 5), recordação na morte/no sono (Parte I, 5), esquecimento (Parte I, 12), brancura (Parte I, 6; Parte II, 8; Parte V, 1), tristeza (Parte I, 8), noite (Parte I, 10 e 16; Parte II, "Nox"; Parte III, 3; Parte V, 13; Final).

É verdade que, se há poemas para os quais a definição da temática é evidente, em outros o embaralhamento de tópicas torna impossível destacar qual é a principal. De qualquer modo, todo o livro mantémse dentro de um campo de referências bastante restrito, cruzadas e recombinadas em várias direções.

Destaca-se nesse campo o sono, tema que atravessa todo o livro. Apenas três dos 49 poemas do livro -4 "Túmulo de Baudelaire" (Parte II), "De profundis clamavi" (Parte II) e poema 6 (Parte V) - não mencionam sonho ou sono nem palavras de mesmo campo semântico (adormecer, dormir, insônia, sonâmbulo, sonolento, por exemplo). Na análise de "Prelúdio", destacamos que o sono sem termo representaria, ao mesmo tempo, a sequência melódica almejada pelo poeta-compositor e o princípio poético estabelecido para seu livro.

Apesar da semelhança fônica, sono e sonho podem designar experiências opostas, como constatamos nesses versos do poema 9, Parte V: "Dir-se-ia / que o amor é sonho, febre, ardor, melancolia, / silêncio, desespero! E a tarde é como um sono / divino que, a um torpor de mágico abandono, / sobre os jardins estende seu delírio vago" (GUIMARAENS, 1916, p. 95, grifo nosso). O sono éapagamento, e o sonho, lembrança. Sonho representa expectativa ainda, sono é esquecimento. Sono se aproxima de inação, paralisia, abandono, anestesia (o sol pode nascer que não haverá reação). Sonho é rememoração do vivido, ou desejo, ou presentificação do que não existe, se realiza durante o sono, mas mantém ligação com movimento (vida) para o passado, para o futuro ou outro plano. No entanto, em um aspecto sono e sonho convergem: ambos representam suspensão.

4 As subseções 2 e 3 da Parte IV não mencionam sono, sonho nem palavras correlatas, mas os termos aparecem nas demais. Como a Parte IV foi considerada um único poema, não a computamos. 


\section{SUSPENSÃO E CINTILÂNCIAS}

Desde o início do texto temos observado que a poesia de Eduardo Guimaraens se constrói em suspensão. Suspensão nas palavras-chave, na ambivalência dos pares de palavras ("sombra ardente", "fulgor tristonho", "perturba" e "fascina"), na característica de cada poema (com destaque para "Prelúdio", poema feito de perguntas) e no livro como um todo, que não se organiza em subordinação, hierarquia, submissão.

A opção por ler Divina quimera como uma fantasia - aposta que se mostrou legítima diante dos paralelos estabelecidos na seção anterior - não encerra nem altera sua instabilidade constitutiva. Isso porque a forma em questão se baseia em procedimentos de variação (quaisquer dos listados na seção “Tema e variações” deste artigo), mas também é livre para incorporar outros materiais e procedimentos - como os encontrados na forma-sonata - sem, no entanto, deixar a música se fixar na qualidade estrita dessa forma. Vale lembrar que inicialmente a fantasia era sinônimo de um "jogo de invenção imaginativa”, de ideia musical estimulante à imaginação, e não designava um gênero composicional específico. Sua origem, calcada na liberdade criativa, garante que cada pequeno momento brilhe, com suas ambivalências e insolúveis mistérios, em paralelo a muitos outros.

Terminamos com Mallarmé (2010, p. 165), poeta cujas propostas teóricas e atualizações poéticas (como nos lembra Ricieri) são as que mais se aproximam da aposta estrutural do livro de Guimaraens:

\footnotetext{
Uma ordenação do livro de versos aponta inata ou por toda parte, elimina o acaso; [...] [no volume] motivos de mesmo jogo se equilibrarão, balanceados, a distância, nem o sublime incoerente da colocação em página romântica nem essa unidade artificial, outrora, medida em bloco no livro. Tudo se torna suspense, disposição fragmentária com alternância e face a face, concorrendo para o ritmo total, o qual seria o poema calado, nos braços; somente traduzido, de certa maneira, por cada pingente.
}

Sim, em Divina quimera cada pingente cintila e contém a natureza do conjunto. Todavia, olhar para os poemas ou para as Partes isoladamente não permitiria dar conta da radicalidade da proposta formal do livro: nem o sublime incoerente do álbum romântico nem a unidade artificial medida em blocos, mas suspense, alternância e equilíbrio de motivos, balanceados, concorrendo para o ritmo total.

Antes de nos calarmos, uma última pergunta: Não seria Quimera uma fantasia? 


\section{REFERÊNCIAS BIBLIOGRÁFICAS}

AGAMBEN, Giorgio. Estâncias: la palavra y el fantasma en la cultura ocidental. Trad. Tomás Segovia. Valência: Pre-textos, 2006.

BALAKIAN, Anna. O Simbolismo. São Paulo: Perspectiva, 2000.

BAS, Julio. Tratado de la forma musical. Trad. Nicolás Lamuraglia. Buenos Aires: Ricordi, 1986.

BAUDELAIRE, Charles. Euvres complètes. 2 vols. Paris: Gallimard, 1975-1976. (Bibliothèque de la Pléiade)

BAUDELAIRE, Charles. As flores do mal. 6ª edição Tradução, introdução e notas de Ivan Junqueira. Rio de Janeiro: Nova Fronteira, 1985.

BROOME, Peter. Baudelaire's Poetic Patterns: The Secret Language of Les Fleurs du Mal. Série Faux Titre, no 166. Amsterdam/Atlanta, GA: Rodopi, 1999.

CUETO JUNIOR, Amancio. Tema com variações. Euterpe - Blog de Música Clássica. 2010. Disponível em: <http://euterpe.blog.br/analise-de-obra/tema-com-variacoes>. Acesso em: 15 set. 2016.

FRIEDRICH, Hugo. Estrutura da lírica moderna: da metade do século XIX a meados do século XX. Trad. Marise M. Curioni. São Paulo: Livraria Duas Cidades, 1991.

GRIPP, Bruno. Forma sonata. Euterpe - Blog de Música Clássica. 2010. Disponível em: <http://euterpe.blog.br/analise-de-obra/forma-sonata>. Acesso em: 15 set. 2016.

GUIMARAENS, Eduardo. Divina quimera. 1a $^{\mathrm{a}}$ ed. Rio de Janeiro: Apollo, 1916.

GUIMARAENS, Eduardo. A divina quimera. 2aㅡ ed. Edição definitiva com prefácio de Mansueto Bernardi. Porto Alegre: Livraria do Globo, 1944.

JAHN, Lívia Petry. A influência de Baudelaire na poesia de Eduardo Guimaraens. Non Plus, São Paulo, 2012, pp. 30-40. Disponível em: <http://www.revistas.usp.br/nonplus/ article/view/44953>. Acesso em: o6 nov. 2016.

MACHADO, Júlio \& MONTEIRO, Sérgio. A função social da forma-sonata. Piano Class (Blog). 1994. Disponível em: <http://pianoclass.com/a-funcao-social-da-formasonata/>. Acesso em: 12 nov. 2016.

MALLARMÉ, Stéphane. Divagações. Trad.eapresentação Fernando Scheibe. Florianópolis: Ed. da UFSC, 2010.

PEIXOTO, Sérgio Alves. A consciência criadora na poesia brasileira - do barroco ao simbolismo. São Paulo: Annablume, 1999. 


$$
\text { A organicidade musical - } 57
$$

RICIERI, Francine (org.). Antologia da poesia simbolista e decadente brasileira. São Paulo: Companhia Editora Nacional/Lazuli Editora, 2007.

RICIERI, Francine Eduardo Guimaraens e Dante. In: Anais do XI Congresso Internacional da ABRALIC. São Paulo: Abralic, 2008, 7 p. Disponível em: <http://www.abralic.org. br/eventos/cong20o8/AnaisOnline/simposios/pdf/o14/FRANCINE_RICIERI.pdf>. Acesso em: 06 nov. 2016.

SCHÜLER, Donaldo. Eduardo Guimaraens. Porto Alegre: IEL (Instituto Estadual do Livro), 1986.

VERAS, Eduardo Horta Nassif. O oratório poético de Alphonsus de Guimaraens: uma leitura do Setenário das Dores de Nossa Senhora. Belo Horizonte: Relicário Edições, 2016. 